\title{
Speaking Across Curriculum in the Public University
}

\author{
Alvin T. Dulin \\ Faculty Member, Cagayan State University-Piat Campus
}

\begin{abstract}
This paper presents the status of Language Across Curriculum (LAC) as an approach in developing the speaking skills of the students in a public university, particularly at Cagayan State University. It provides baseline data on how English teachers, content area teachers, administrators, and administrative personnel develop students' speaking skills in school-based speaking transactions and learning experiences. The study utilizes the descriptive method of research employing survey and comparative techniques supplemented by Focus Group Discussion and actual voice recordings. Findings reveal that LAC is adopted as an approach in developing the speaking skills of students; however, the efforts in carrying this out are not consistent due to the lack of a policy requiring the use of English in school-based communications. Both students and teachers assess that students do not receive maximum development of their speaking skills due to limited exposure to the use of English. Training and orientation on the role of the school community members, most especially among content-area teachers and administrative personnel, and more extensive use of English as a medium of communication in the school are highly encouraged.
\end{abstract}

Keywords---environment and speaking, language across curriculum, teaching speaking.

\section{Introduction}

The teaching of English is not only an English teacher's task. It requires collaboration among all members of the school community to provide authentic language experiences to students may it be in the classroom, library, offices, or simply in the school canteen. The school administrators and facilitative staff, content area teachers, and language teachers all have a share to do to fully develop and achieve students' improved language proficiency in English. Unfortunately, this collaboration is not achieved all the time.

Linguistics and Culture Review (c) 2021.

Corresponding author: Dulin, $A$. T.; Email: dulinalvin@yahoo.com

Manuscript submitted: 15 April 2021, Manuscript revised: 9 June 2021, Accepted for publication: 2 July 2021

100 
Many Asian counties have overtaken the Philippines in terms of English proficiency standing. True to this, the Hopkins International Report, which is the official Philippine representative to the group called Test of English for International Communication (TOEIC), reveals that the level of English proficiency of college graduates from the Philippines is lower than the target English proficiency of high school students in Thailand and Vietnam (Domingo, 2018). Also, McLean (2010) cites that employers in the industries have to reject 95 of 100 job applicants because their English proficiency, most especially in speaking, is inadequate. Moreover, the portion of college graduates among the unemployed also increased from 15.8 percent in 2004 to 18 percent in 2013 and this is greatly attributed to the diminishing English language proficiency of graduates.

One major factor which causes the decline of the English proficiency of Filipinos, particularly of college students is revealed by a study conducted by Opetina \& Laxa (2000) - lack of exposure in using it not only outside but even inside the school. This is most especially in acquiring speaking skills wherein actual exposure to language tasks plays a very important part in the process of learning how to use the English language.

Among the five macro-skills, speaking is the most reflective of one's English proficiency because it is readily observable and utilized. It is the most conducive and usual medium of communication yet the most complex to teach and learn making this skill most challenging to deal with.

One of the pedagogic approaches that are used in teaching English nowadays is Language Across Curriculum. LAC is an approach that integrates language learning and content learning (Quong \& Linder, 2014). This requires the integration of language arts in teaching not only speaking but all the other macroskills while teaching in the content areas of social studies, mathematics, science, music, and the arts. This is grounded on the principle that language plays a central role in learning and that no matter what is the subject area, students assimilate new concepts largely through language, which is when they communicate about what they are learning and relate this to what they already know. This in effect will not only increase learning in the content areas but develop language proficiency.

But not only are the teachers involved in this language learning. Vollmer (2006) explains that LAC develops mainly through its purposeful and contextualized use, hence the need for a supportive language environment where all the rest of the personalities in the school should offer real-life communicative experience. Misra (2015) clarifies that the concept of LAC has three central tenets and these are that (1) language is more than surface structure, (2) the entire school as an environment influences students' language development, and (3) language plays a key role in virtually all school learning.

If fully established, LAC promises the following benefits. First, it allows students to improve language competence. Second, it makes it easier for learners to acknowledge the immediate relevance of second language skills which increases the motivation for learning a second language. And third, it can be used to 
introduce subject-specific English which helps to prepare the learners for the workplace (Nawratil, 2012).

LAC can be the key towards improving the English proficiency of Filipinos and this study is devoted to investigating the status of this approach in developing the speaking skills of students in a public university in the Philippines, particularly at the Cagayan State University (CSU). Hence, this study is aimed at assessing how speaking skills are developed across the curriculum in CSU. Specifically, it answered the following questions.

- What is the profile of the students in terms of:

- Age

- Sex

- Course

- Area of specialization

- How do content area teachers and English teachers develop students' speaking skills across the curriculum?

- How do the administrative, facilitative, and teaching personnel help develop the students' speaking skills?

- Is there a difference between how the English teachers and content area teachers develop students' speaking skills?

- Is there a difference in the status of speaking across the curriculum as perceived by the students when grouped according to their profile variables?

\section{Method}

This study utilized the descriptive research method, employing survey and comparative techniques. Supplemental strategies such as the Focus Group Discussion (FGD) and actual voice recordings in different communicative settings in the school were also used. The study was conducted in the 8 campuses of Cagayan State University particularly at the colleges of Teacher Education and Information Technology, which are the colleges common on all campuses (Khan, 2013; Akdemir et al., 2012).

The respondents of the study were the 29 administrators of Cagayan State University, which included the campus executive officers, university deans, and associate deans. The study also involved 78 content-area teachers, 27 English teachers, and 358 third-year students enrolled during the 2nd Semester of School Year 2015-2016. Total enumeration was used in selecting the administrators and teachers. Only teachers with at least three years of teaching experience were considered. Stratified sampling was used in selecting the student-respondents (Rubin \& Smith, 1990; Pattni et al., 2019).

The main data gathering tools were the questionnaire for each group of respondents and interview guides. All concepts in the questionnaires were derived from existing laws on language in the Philippines such as the Bilingual Education Policy, Commission on Higher Education memoranda, the principles of Language Across Curriculum, and the guidelines in the implementation of LAC in South Africa English Across Curriculum (EAC) Integration Program 
(http://www.education.gov.za) and the Language Arts Across Curriculum Program of Hong Kong (http:/ / www.edb.gov.hk).

The following scale was used to describe the status of speaking across the curriculum as perceived by English teachers and content area teachers. It was also used to describe the assessment of the students on how the administrators, facilitative staff, and the teachers develop their speaking skills.

- $4.20-5.0$

Always (Very satisfactory)

- $3.40-4.19 \quad-\quad$ Often

- $2.60-3.39 \quad$ - $\quad$ Sometimes (Somewhat satisfactory)

- $1.80-2.59 \quad$ - $\quad$ Seldom (Fair)

- $1.0-1.79 \quad-\quad$ Never (Poor)

ANOVA was used to compute for the difference of the students' assessment on the status of Speaking across Curriculum (SAC) when grouped according to their course. T-test was used to determine the difference in the status of SAC as perceived by the students grouped according to their sex and the status of SAC among English teachers and content area teachers (Yang et al., 2013; Kothgassner et al., 2016).

\section{Discussion}

Profile of the Students

As shown in Table 1, the majority of the students are female numbering 249 or 69.55 percent of their total while 30.45 percent of them are males. This implies that Education and IT courses are more subscribed by females. On age, most are from 18 to 20 years old comprising 86.31 percent of the total number. The table further reveals that most of the students are enrolled in the College of Teacher Education taking up Bachelor of Secondary Education and Bachelor of Elementary Education comprising 122 or 34.08 percent and 72 or 20.11 percent respectively.

Table 1

Profile of the students

\begin{tabular}{lll}
\hline Category & $\begin{array}{l}\text { Frequency } \\
(\mathrm{n}=358)\end{array}$ & Percentage \\
\hline Sex & 249 & \\
Female & 109 & 69.55 \\
Male & & 30.45 \\
Age & 309 & \\
$18-20$ & 35 & 86.31 \\
$21-23$ & 11 & 9.78 \\
$24-26$ & 2 & 3.07 \\
$27-29$ & 1 & 0.56 \\
$30-32$ & & 0.28 \\
Course & 72 & \\
Bachelor of Elementary Education & 122 & 20.11 \\
Bachelor of Secondary Education & & 34.08 \\
\hline
\end{tabular}




\begin{tabular}{lll}
\hline $\begin{array}{l}\text { Bachelor of Science in Information } \\
\text { Technology }\end{array}$ & 164 & 45.81 \\
\hline
\end{tabular}

Speaking Across Curriculum as Carried Out by Content Area Teachers and English Teachers

As gleaned from Table 2, the English teachers lead in the teaching of speaking because they teach it 'very satisfactorily' with the weighted mean of 4.24 compared with the status of speaking instruction among content area teachers which is 'somewhat satisfactory' with the weighted mean of 3.07. Both groups reveal that they 'always' model correct grammar although the English teachers rated themselves higher with the mean of 4.63 compared with the mean of the content area teachers which is 4.59 . This result shows a good indication that the teachers, regardless of the subject being taught, are confident in their proficiency in speaking English and this should result in good classroom instruction. Faez (2011) found out that teachers' confidence in their level of language proficiency boosts their ability to conduct all classroom functions through the medium of the target language.

Moreover, English teachers reveal that they 'always' contextualize their topic through the language that they use with the mean of 4.70 compared with content area teachers with the mean of 4.17 or 'often.' English teachers do more interactive speaking activities as they 'always' do these with the mean of 4.41 than the content area teachers who only 'often' do so with the mean of 3.99. This denotes that students have more speaking time during their English subjects than during their other subjects (Lyster, 2015; Kalinowski et al., 2020).

On creative speaking, the English teachers 'always' conduct activities in which students showcase creative language use with the mean of 4.67 and 'always' conduct activities that display the students' ability to manipulate language to evoke audience response with the mean of 4.37. On the other hand, the content area teachers reveal that they 'sometimes' do the same activities with the means of 2.77 and 2.78 respectively. These prove that students need more opportunities to display their speaking prowess during their content area subjects (Hayes, 2009; Rahimi \& Zhang, 2015; Jafarova, 2021).

The findings above are further manifested through the disparity between the frequencies of the conduct of speaking performance activities between the two groups of teachers. The content area teachers 'seldom' conduct debate, interview, role-play, and speech delivery with the means of $2.07,2.23,1.94$, and 1.88 respectively compared with the English teachers who 'often' do all these with the means of $3.41,3.63,3.96$ and 3.89 in the same order. The only speaking activity that content area teachers 'often' conduct is brainstorming with the mean of 3.07 compared with English teachers who 'always' do so with the mean of 4.37. During an interview with some content area teachers, they revealed that these activities are somewhat not applicable or appropriate in their subjects most especially for Science and Math teachers.

Furthermore, there is a big disparity between the means of the two groups of teachers in terms of developing students' use of general academic language and 
creating a classroom environment where students have real-life communication, authentic activities, and meaningful tasks that promote the oral language. The content area teachers reveal that they 'sometimes' do the said activities with the same mean of 2.96 compared with English teachers who reveal that they 'always' do these with the means of 4.30 and 4.48. These are manifestations that students get better support and exposure in expressing themselves through speaking in their English subjects than in their content area subjects.

Table 2

Speaking across the curriculum as carried out by content area teachers and English teachers

\begin{tabular}{|c|c|c|c|c|}
\hline \multirow{2}{*}{ Indicators } & \multicolumn{2}{|c|}{$\begin{array}{l}\text { Content Area } \\
\text { Teachers }\end{array}$} & \multicolumn{2}{|c|}{ English Teachers } \\
\hline & Mean & $\begin{array}{l}\text { Adjectival } \\
\text { Value }\end{array}$ & Mean & $\begin{array}{l}\text { Adjectival } \\
\text { Value }\end{array}$ \\
\hline I model correct grammar. & 4.59 & Always & 4.63 & Always \\
\hline $\begin{array}{l}\text { I contextualize my topic through the } \\
\text { language that I use. }\end{array}$ & 4.17 & Often & 4.70 & Always \\
\hline $\begin{array}{l}\text { I allot time for my students to interact } \\
\text { through speaking. }\end{array}$ & 3.99 & Often & 4.41 & Always \\
\hline $\begin{array}{l}\text { I say explanations with gestures, } \\
\text { objects, and elements that help the } \\
\text { student to understand the subject } \\
\text { more easily. }\end{array}$ & 3.96 & Often & 4.44 & Always \\
\hline $\begin{array}{l}\text { I include the discussion and use of } \\
\text { subject-specific vocabulary as one part } \\
\text { of my lesson. }\end{array}$ & 3.30 & Sometimes & 3.85 & Often \\
\hline $\begin{array}{l}\text { I give the simpler meaning of high } \\
\text { sounding words. }\end{array}$ & 4.10 & Often & 4.44 & Always \\
\hline $\begin{array}{l}\text { I conduct activities in which students } \\
\text { can showcase creative language use. }\end{array}$ & 2.77 & Sometimes & 4.67 & Always \\
\hline $\begin{array}{l}\text { I conduct activities that display } \\
\text { students' ability to manipulate } \\
\text { language in order to evoke audience } \\
\text { response. }\end{array}$ & 2.78 & Sometimes & 4.37 & Always \\
\hline $\begin{array}{l}\text { I infuse awareness of and sensitivity to } \\
\text { language use on cultural issues. }\end{array}$ & 3.00 & Sometimes & 4.44 & Always \\
\hline $\begin{array}{l}\text { I explain to my students my language } \\
\text { of giving directions and routinely } \\
\text { expressions in managing the class } \\
\text { (peripheral language). }\end{array}$ & 3.23 & Sometimes & 4.41 & Always \\
\hline $\begin{array}{l}\text { I develop students' use of general } \\
\text { academic language such as giving } \\
\text { phrases or expressions to help them } \\
\text { organize ideas, express opinions, } \\
\text { disagree or discuss a point. }\end{array}$ & 2.96 & Sometimes & 4.30 & Always \\
\hline $\begin{array}{l}\text { I create a classroom environment } \\
\text { where students have real-life } \\
\text { communication, authentic activities, }\end{array}$ & 2.96 & Sometimes & 4.48 & Always \\
\hline
\end{tabular}


and meaningful tasks that promote

oral language.

I conduct the following activities:

Debate

2.07

Interview

2.23

Seldom

3.41

Often

Role-play

1.94

Seldom

3.63

Often

Speech delivery

1.88

Seldom

3.96

Often

Group discussion

3.32

Improvised drama

1.79

Seldom

3.89

Often

Oral report

2.91

Sometimes

4.48

Always

Brainstorming

3.52

Never

3.81

Often

Weighted Mean

3.07

Sometimes

4.15

Often

Often

4.37

Always

Somewhat $\quad 4.24$

Very

Satisfactory

Satisfactory

Comparison on the Development of Speaking Skills between the Content Area Teachers and English Teachers

Presented in Table 3 is the result of the t-test for independent groups. The computed t-value of 8.328 has an associated probability of 0.000 , thus, there exists a difference in how the English teachers develop speaking from how content area teachers do (Aiguo, 2007; Ginaya et al., 2018; Ritonga et al., 2021).

A perusal of the summated mean scores reveals that English teachers (284.96) have more tendencies to develop speaking skills as compared with the content area teachers (212.40). This implies that English teachers are fully aware and actualizing their greater responsibility in developing the speaking skills of the students while the content area teachers focus on the acquisition of the subject content giving less emphasis on developing such skills.

Table 3

Comparison of the development of speaking skills between the content area teachers and English teachers

\begin{tabular}{lcrlll}
\hline Group & Mean & SD & $\begin{array}{l}\text { Std. Error of } \\
\text { Difference }\end{array}$ & $\begin{array}{l}\text { Computed } \\
\text { t-value }\end{array}$ & Probability \\
\hline $\begin{array}{l}\text { Content Area } \\
\text { Teachers }\end{array}$ & 212.40 & 52.879 & 8.713 & $8.328^{* *}$ & 0.000 \\
$\begin{array}{l}\text { English Teachers } \\
* *=\text { significant at } 0.01 \text { level }\end{array}$ & $\mathrm{df}=103$ & & &
\end{tabular}

Assessment on How Administrative, Facilitative and Teaching Personnel Develop Students' Speaking Skills

- Administrative and Facilitative Personnel

Table 4 reveals that the administrative and facilitative personnel develop the speaking skills of the students 'somewhat satisfactorily' with the weighted mean of 2.67. Specifically, the table reveals that the strength of the administrative and facilitative staff is that announcements and other notices in the different offices are 'always' expressed in English with a mean of 4.44. Their weakness, on the 
other hand, is that they 'seldom' require students to transact business with them in English with the mean of 2.48. The table further reveals that the administrative offices in CSU only 'sometimes' implement a Speak English Policy with the mean of 2.97 and that the college dean's office is most consistent with the highest mean of 3.17

During the FGD, the students revealed that the cashiers, accountants, registrars, school dentists, school nurses, security guards, and utility workers indeed "rarely" use English at the level of 1 out of the scale of 1-10, 10 being the highest. The students also revealed that the OSSW coordinators, librarians, and secretaries, "sometimes" speak English when they are transacting business with them. They also added that CEO's and deans tend to use English in public speeches but generally speak in Filipino during ordinary one-on-one or day-to-day encounters. Worthy to mention is the guidance counselors who according to the students "often" speak English with them but they would shift to Filipino as a strategy when students do not open up during counseling. The students claim that they want more exposure to speaking English to become proficient and to prepare for their future jobs.

Table 4

Assessment on how administrative and facilitative personnel develop students' speaking skills

\begin{tabular}{lll}
\hline Indicators & Mean & $\begin{array}{l}\text { Adjectival } \\
\text { Value }\end{array}$ \\
\hline The administrative offices in CSU implement a Speak & 2.79 & Sometimes \\
English Policy. & 2.48 & Seldom \\
The administrative personnel requires students to & & \\
transact business with them in English. & 2.89 & Sometimes \\
In general, the administrative staff helps students learn & & \\
better English as the students transact business with & & \\
them. & 4.44 & Always \\
Announcements and other notices in the different offices & 4.42 & Sometimes \\
are expressed in English. & 3.12 & \\
The administrative personnel influence positively the & & \\
English abilities of the students. & & \\
The following offices require the students to transact & & \\
business in English. & 3.03 & Sometimes \\
Campus Executive Officer's Office & 3.17 & Sometimes \\
College Dean's Office & 2.69 & Sometimes \\
Office of the Student Services and Welfare & 2.77 & Sometimes \\
Guidance Office & 2.49 & Seldom \\
Accounting Office & 2.53 & Seldom \\
Registrar's Office & 2.38 & Seldom \\
Library & 2.39 & Seldom \\
Clinic & & \\
The following employees speak with students in English. & 2.30 & Seldom \\
Secretaries & 1.62 & Never \\
Security Guards & 1.66 & Never \\
Utility Staff & & \\
\hline & &
\end{tabular}




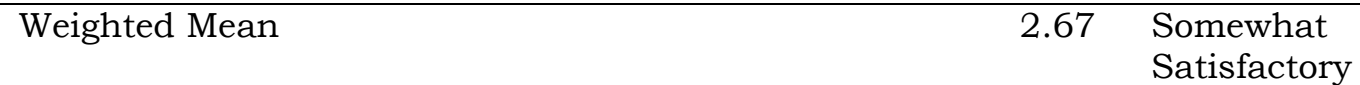

- Faculty Members

Data in Table 5 is the students' assessment on how teachers across the curriculum develop their speaking skills as they communicate with them. As reflected in the table, the English teachers generally perform 'satisfactorily' with the weighted mean of 3.97 while the content area teachers perform 'somewhat satisfactorily' with the weighted mean of 3.25.

Moreover, the students rated both groups low on speaking English with them outside the classroom revealing that content area teachers 'seldom' do with the mean of 2.54 and that the English teachers 'sometimes' do so with the mean of 3.36. This finding implies that the teachers usually do not have the intention to further develop students' English proficiency through spoken discourse outside the classroom. This results in limited exposure and opportunities for students to use English in authentic settings. During the Focus Group Discussion, the students revealed that the teachers commonly use their native language or Filipino in communicating with them outside the classroom. The students further revealed that only the English teachers would use English but in a very rare and inconsistent manner. "Teachers also very seldom speak English even at the faculty room," they added, and that they are not required to transact business in English inside the said room.

Moreover, the table shows that the content area teachers 'sometimes' model the language of their subject very well with the mean of 3.25 while the English teachers 'often' do so with the mean of 4.22. On clarifying words or phrases that students do not understand, the content area teachers 'sometimes' do so with the mean of 3.39 while the English teachers 'often' do the same with the mean of 4.18. The students also reveal that content area teachers 'sometimes' teach effective communication with the mean of 2.23 while the English teachers 'often' do the same with the mean of 3.36 .

When asked "What are the common speaking activities that non-English teachers conduct to develop your English skills?" the students respond, "We do a lot of small-group discussions, recitations, and oral reports." They further said that some content area teachers give reading assignments and let them react through speaking. Through the FGD it was further discovered that non-English teachers help students in dealing with their difficulties in speaking English by usually correcting their grammar and pronunciation and assisting them in thinking of the words to express themselves while speaking. These are the ways through which non-English teachers contribute to the speaking fluency of the students. 
Table 5

Status of speaking across the curriculum as manifested in the manner teachers transact business with students

\begin{tabular}{|c|c|c|c|c|}
\hline \multirow{2}{*}{ Indicators } & \multicolumn{2}{|c|}{$\begin{array}{l}\text { Content Area } \\
\text { Teachers }\end{array}$} & \multicolumn{2}{|c|}{ English Teachers } \\
\hline & Mean & $\begin{array}{l}\text { Adjectival } \\
\text { Value }\end{array}$ & Mean & $\begin{array}{l}\text { Adjectival } \\
\text { Value }\end{array}$ \\
\hline $\begin{array}{l}\text { The teachers speak English with } \\
\text { students outside the classroom. }\end{array}$ & 2.54 & Seldom & 3.36 & $\begin{array}{l}\text { Sometime } \\
\mathrm{s}\end{array}$ \\
\hline $\begin{array}{l}\text { The teachers teach how to effectively } \\
\text { communicate through speaking. }\end{array}$ & 3.23 & Sometimes & 4.08 & Often \\
\hline $\begin{array}{l}\text { The teachers clarify words or phrases } \\
\text { that students don't understand. }\end{array}$ & 3.39 & Sometimes & 4.18 & Often \\
\hline $\begin{array}{l}\text { The teachers give practical speaking } \\
\text { tests. }\end{array}$ & 3.37 & Sometimes & 4.15 & Often \\
\hline $\begin{array}{l}\text { The teacher's train/teach students to } \\
\text { become good in English by giving } \\
\text { activities in speaking (e.g. speeches, } \\
\text { oral reports, dramatization, interviews, } \\
\text { skits, etc.) }\end{array}$ & 3.48 & Often & 4.10 & Often \\
\hline $\begin{array}{l}\text { The teachers assist students in dealing } \\
\text { with their difficulties in speaking }\end{array}$ & 3.46 & Often & 3.96 & Often \\
\hline Weighted Mean & 3.25 & $\begin{array}{l}\text { Somewhat } \\
\text { Satisfactor } \\
\text { y }\end{array}$ & 3.97 & $\begin{array}{l}\text { Satisfactor } \\
\mathrm{y}\end{array}$ \\
\hline
\end{tabular}

Comparison on the Status of Speaking across Curriculum as Assessed by the Students Grouped according to Their Profile Variables

- According to Sex

In a comparison of the students' assessment when grouped according to sex, Table 6 shows that the t-computed value of 0.020 has an associated probability greater than 0.05. It means that there is no significant difference in the assessment of the students on how their speaking skills are developed by the different groups of people in the school when grouped according to their sex. Students share the same experiences and exposures on speaking English regardless of sex.

Table 6

Comparison of the students' assessment on the status of speaking across the curriculum when grouped according to sex

\begin{tabular}{lllllll}
\hline Group & Mean & SD & $\begin{array}{l}\text { Std. Error } \\
\text { of } \\
\text { Difference }\end{array}$ & $\begin{array}{l}\text { Computed } \\
\text { t-value }\end{array}$ & Probability & Decision \\
\hline Female & 3.40 & 0.458 & 356 & 0.020 & 1.960 & Not \\
\hline
\end{tabular}




\begin{tabular}{llll}
\hline Male & 3.27 & 0.471 & Significant
\end{tabular}

- According to Degree Program

Table 7 presents the results of the analysis of variance on the assessment of Speaking across Curriculum as assessed by students grouped according to a degree program. The $\mathrm{F}$ ratio of 563.084 has an associated probability lower than 0.01 ; thus, the null hypothesis is rejected.

This result means that the students' course is a distinguishing factor regarding their experiences along speaking English. Based on the summated mean scores, the students enrolled in teacher education have higher assessments than the students in the information technology. This is attributed to the fact that students in Bachelor of Secondary Education and Bachelor of Elementary Education are expected to be well-trained in teaching speaking to their future students. To ensure this transferability of skills, they need to acquire the skills first; hence, they are exposed to more varied, rigid, and extensive language teaching strategies and learning opportunities much more than those taught in information technology.

Table 7

Analysis of variance on the status of speaking across curriculum as assessed by students grouped according to their degree programs

\begin{tabular}{llllll}
\hline & Sum of Squares & Mean Square & & \\
Source of Variance & & df & & F-ratio & Prob. \\
\hline Between Groups & 3215423.955 & 2 & 1607711.978 & & \\
Within Groups & 1013592.975 & 355 & 2855.191 & $563.084^{* *}$ & .000 \\
Total & 4229016.930 & 357 & & & \\
\hline
\end{tabular}

** $=$ significant at 0.01 level

Problems Encountered by Content Area Teachers, English Teachers, and Administrators on Language Across Curriculum

The content area teachers, English teachers, and administrators cited problems in the free-response part of the questionnaire and it yielded the following data. 'Lack of training on LAC' ranks first among the problems. Under this, most of the teachers explain that they need to become more aware of LAC through seminars and training. The second is the lack of training on English proficiency among teachers. Third, are two problems - lack of instructional materials/ references/ media/ technology and poor English proficiency of the teachers.

On lack of materials and references, the respondents detail out mentioning that there is a "lack of instructional modules locally developed," "lack of resources based on content," and "There are no available published materials to be used by the faculty." On the other hand, the poor English proficiency of teachers is one common problem among all groups. Here, the administrator's comment, "Some faculty members are not proficient in the use of English language" and "Some English teachers are not proficient in the delivery of their lessons/topics." The 
rest comment, "There are teachers who cannot even express themselves in English." Based on these, it could be inferred that a public university such as CSU cannot fully apply the concepts of LAC because it is insufficient with the basic and major requirements which are concept orientation, capacity building, and materials development.

\section{Conclusion}

Deducing from the findings, the researcher arrived at the following general inferences. Language across Curriculum is adopted as an approach in developing the English speaking skills of students in a public university like the Cagayan State University. However, the efforts in carrying this out are not consistent due to the lack of a policy requiring the use of English in school-based communications. Both students and teachers assess that students do not receive maximum development of their speaking skills due to limited exposure in the use of English, especially in settings outside the classroom and particularly with the content area teachers, administrative and facilitative staff.

\section{Acknowledgments}

The researcher is grateful to the administrators, faculty, and students of Cagayan State University, particularly those who are in the College of Teacher Education and College of Information Technology.

\section{References}

Aiguo, W. (2007). Teaching aviation English in the Chinese context: Developing ESP theory in a non-English speaking country. English for Specific Purposes, 26(1), 121-128. https://doi.org/10.1016/j.esp.2005.09.003

Akdemir, A. S., Barin, M., \& Demiroz, H. (2012). Broadsheet English: teaching speaking through newspaper articles. Procedia-Social and Behavioral Sciences, 46, 3967-3971. https://doi.org/10.1016/j.sbspro.2012.06.180

Domingo, K. (2018). PH lacks English standard ahead of BPO shift to artificial intelligence.

Faez, F. (2011). Reconceptualizing the native/nonnative speaker dichotomy. Journal of Language, Identity \& Education, 10(4), 231-249.

Ginaya, G., Rejeki, I. N. M., \& Astuti, N. N. S. (2018). The effects of blended learning to students' speaking ability. International journal of linguistics, literature and culture, 4(3), 1-14.

Hayes, D. (2009). Non-native English-speaking teachers, context and English language teaching. System, 37(1), 1-11. https://doi.org/10.1016/j.system.2008.06.001

Jafarova, K. A. (2021). The role of extralinguistic factors in interlingual relations and theoretical issues of interference. Linguistics and Culture Review, 5(1), 4352. https://doi.org/10.37028/lingcure.v5n1.415

Kalinowski, E., Egert, F., Gronostaj, A., \& Vock, M. (2020). Professional development on fostering students' academic language proficiency across the curriculum-A meta-analysis of its impact on teachers' cognition and teaching practices. Teaching and Teacher Education, 88, 102971. https://doi.org/10.1016/j.tate.2019.102971 
Khan, I. (2013). Speaking skills and teaching strategies: The case of an EFL classroom. Elixir International Journal, 58(10), 14557-14560.

Kothgassner, O. D., Felnhofer, A., Hlavacs, H., Beutl, L., Palme, R., KryspinExner, I., \& Glenk, L. M. (2016). Salivary cortisol and cardiovascular reactivity to a public speaking task in a virtual and real-life environment. Computers in Human Behavior, 62, 124-135. https://doi.org/10.1016/j.chb.2016.03.081

Lyster, R. (2015). Using form-focused tasks to integrate language across the immersion curriculum. System, 54, https://doi.org/10.1016/j.system.2014.09.022

McLean, J. (2010). For Filipinos, English proficiency is fading. Retrieved on July, 8, 2016.

Misra, Pa. (2015). Language Across Curriculum': Need for a paradigm shift.

Nawratil, I. (2012). Language Across Curriculum. Second Language Acquisition: The Interface between theory and Practice.

Opetina, L. N., \& Laxa, M. J. G. (2000). Factors Influencing English Language Proficiency of TIP Freshman Students of TIP Manila. TIP Research Journal Manila, 5(1), 1-1.

Pattni, N., Arzola, C., Malavade, A., Varmani, S., Krimus, L., \& Friedman, Z. (2019). Challenging authority and speaking up in the operating room environment: a narrative synthesis. British journal of anaesthesia, 122(2), 233244. https://doi.org/10.1016/j.bja.2018.10.056

Quong, T. \& Linder, S. (2014). Language Across the Curriculum. Jockey Club Ti-I College.

Rahimi, M., \& Zhang, L. J. (2015). Exploring non-native English-speaking teachers' cognitions about corrective feedback in teaching English oral communication. System, 55, 111-122. https://doi.org/10.1016/j.system.2015.09.006

Ritonga, M., Kustati, M., Budiarti, M., Lahmi, A., Asmara, M., Kurniawan, R., Putri, N., \& Yenti, E. (2021). Arabic as foreign language learning in pandemic COVID-19 as perceived by students and teachers. Linguistics and Culture Review, 5(1), 75-92. https://doi.org/10.37028/lingcure.v5n1.726

Rubin, D. L., \& Smith, K. A. (1990). Effects of accent, ethnicity, and lecture topic on undergraduates' perceptions of nonnative English-speaking teaching assistants. International journal of intercultural relations, 14(3), 337-353. https://doi.org/10.1016/0147-1767(90)90019-S

Vollmer, H. J. (2006). Towards a common European instrument for language (s) of education. Expertise für den Europarat, Language Policy Division.

Yang, Y. T. C., Chuang, Y. C., Li, L. Y., \& Tseng, S. S. (2013). A blended learning environment for individualized English listening and speaking integrating critical thinking. Computers \& Education, 63, 285-305. https://doi.org/10.1016/j.compedu.2012.12.012 